\title{
Spastisitet etter ryggmargsskade
}

Engelsk oversettelse på www.tidsskriftet.no

\begin{abstract}
Sammendrag
Bakgrunn. Opptil $70 \%$ av pasientene med ryggmargsskader utvikler spastisitet. Hovedformålet med artikkelen er å gi en oversikt over håndteringen av spastisitet primært hos pasienter med ryggmargsskade.
\end{abstract}

Kunnskapsgrunnlag. Artikkelen er basert på litteratursøk i PubMed med søkeordene «spasticity» og «spasticity AND spinal cord injury» samt egne kliniske erfaringer og forskning.

Resultater. Spastisitet kan være generell, regional eller lokalisert. Tilstander som overfylt urinblære, obstipasjon, akutte infeksjoner, syringomyeli eller beinbrudd kan påvirke graden av spastisitet betydelig og skal kartlegges. Vurdering av de kliniske og funksjonelle konsekvensene for pasienten er avgjørende for valg av tiltak. Egenaktivitet, fysioterapi og perorale medikamenter er de enkleste og billigste alternativene. Baklofen er det eneste sentraltvirkende muskelrelakserende medikamentet som er registrert i Norge og er førstevalget ved peroral behandling. Benzodiazepiner kan også brukes. Effekten av tabletter er generelt begrenset og bivirkningene ofte fremtredende. Lokal spastisitet kan behandles med botulinumtoksininjeksjoner. Effekten er tidsbegrenset og behandlingen må gjentas. Internasjonale retningslinjer anbefaler at man kombinerer injeksjoner med botulinumtoksin med fysioterapi. Ved regional spastisitet, spesielt i underekstremitetene, kan intratekal baklofen via en programmerbar pumpe gi kontinuerlig spasmedempende effekt. Ortopediske eller nevrokirurgiske inngrep kan være et alternativ hos utvalgte pasienter med intraktabel spastisitet.

Fortolkning. Spastisitet etter ryggmargsskade må fortløpende vurderes. Behandlingsstrategi avhenger av lokalisasjon og graden av funksjonssvikt forårsaket av spastisiteten.

\section{Tiina Rekand}

tiina.rekand@helse-bergen.no

Ellen Merete Hagen

Nevrologisk avdeling

Haukeland universitetssykehus

\section{Marit Grønning}

Nevrologisk avdeling

Haukeland universitetssykehus og

Institutt for klinisk medisin

Universitetet i Bergen

Spastisitet er et relativt vanlig fenomen hos pasienter med sykdom eller skade i sentralnervesystemet og er et tegn på skade av øvre motornevron. Opptil $70 \%$ av pasientene med ryggmargsskade utvikler spastisitet som kan medføre betydelige plager (1-4). Hvordan spastisiteten utvikler seg og graden av spastisitet avhenger av skadens lokalisasjon og grad (om skaden er komplett eller inkomplett). Spastisitet kan utvikles måneder og år etter den akutte skaden og føre til økt funksjonstap og hospitalisering (3).

W. Lance definerte spastisitet som «en motorisk svikt karakterisert ved hastighetsavhengig økning i muskeltonus med økte senereflekser på grunn av hypereksitabilitet i strekkerefleksene» (5). Den europeiske samarbeidsgruppen EUSPASM har definert spastisitet som «forstyrrelse av sensoriskmotorisk kontroll som resultat av skade av øvre motornevron, som kommer til syne som intermitterende eller varig involuntær aktivering av muskler» (6). Øvre motornevronskade forårsaker i tillegg pareser, nedsatt finmotorikk og kontroll over bevegelser samt økt trettbarhet ved bevegelser $(6,7)$.

Formålet med artikkelen er å gi en oversikt over patofysiologi, klinisk bilde og behandling av spastisitet hos primært pasienter med ryggmargsskade. Artikkelen kan være til hjelp for leger som er involvert i behandlingen av spastisitet hos pasienter med ryggmargsskade.

\section{Kunnskapsgrunnlag}

Artikkelen er basert på litteratursøk i PubMed med søkeordene «spasticity» og «spasticity AND spinal cord injury», med hovedvekt på kliniske studier. Våre vurderinger hviler dessuten på egne kliniske erfaringer og forskning ved Spastisitetsklinikken, Haukeland universitetssykehus.

\section{Patofysiologi}

Patogenesen for utvikling av spastisitet hos pasienter med ryggmargsskade er multifak- toriell. Endring i eksitabilitet i forskjellige supraspinale inhibitoriske nervebaner ble tidligere sett på som hovedforklaringen. Nyere forskning har vist endret eksitabilitet også i selve motornevronene og internevronene (8). Spastisitet kan være enten generell, regional eller lokalisert og knyttet til tetraparese, hemiparese, paraparese eller monoparese. Spastisitet kan være forårsaket av cerebrale eller spinale skader (9). Spastisitet er ikke et statisk fenomen, og ubehandlet kan det føre til sekundær omorganisering av både nervesystemet og muskulaturen (7). Ved alvorligere ryggmargsskade oppstår pareser som fører til adaptiv forkortelse av muskler som forandrer afferent input til ryggmargen. Dette forsterker spastisiteten og medfører utvikling av kontrakturer, feilstillinger og ytterligere funksjonstap. Denne utviklingen kan påvirkes gjennom tidlig aktivitet og medikasjon $(10,11)$.

Lett til moderat spastisitet kan ha positiv effekt på funksjonen. Blant annet kan spastisitet gjøre det mulig for pasienter med pareser i beina å oppnå ståfunksjon og enklere forflytning fra for eksempel seng til stol (12). Lett til moderat spastisitet bidrar til bedre sirkulasjonen i beina, slik at man unngår ødemer og reduserer risiko for utvikling av dyp venetrombose $(13,14)$.

Uttalt spastisitet kan bidra til økt funksjonssvikt, kontrakturer, feilstillinger, sår og smerter. For å unngå en slik negativ utvikling bør behandlingen starte så tidlig som mulig (15).

\section{Klinisk vurdering}

Ved vurdering av spastisitet er det helt nødvendig med en grundig beskrivelse av spastisitetens omfang og grad samt effekt på pasientens daglige funksjon og livskvalitet (16).

\section{Hovedbudskap}

- Spastisitet er en hyppig komplikasjon etter ryggmargsskade og kan bidra til ytterligere funksjonsnedsettelse

- Indikasjon for behandling baseres på kartlegging og vurdering av pasientens funksjonstap og klinisk unders $\emptyset$ kelse

- De mest brukte medikamentelle behandlingstilbudene er baklofen administrert peroralt eller intratekalt og gjentatte intramuskulære injeksjoner med botulinumtoksin 
Spastisitet kan hindre forflytning, påvirke plasseringen av bein i rullestol eller i bil, vanskeliggjøre hygiene av hånden, gi problemer med kateterisering og forårsake smerter. Hvis pasienten selv ikke kan gjøre rede for sine plager, bør man få opplysninger fra de som kjenner han/henne best. Ved vurdering av ulike behandlingsalternativer inngår også vurdering av hva som eventuelt kan oppnås.

I den kliniske undersøkelsen er det viktig å kartlegge aktiv og passiv bevegelsesevne kombinert med eventuelle komplikasjoner som smerter og/eller feilstillinger i ledd. De mest utbredte skåringsskalaene er Ashworthskala og modifisert Ashworth-skår (17). Ved skåring med Ashworth-skala vurderes motstanden i leddet ved passive bevegelser (18). Denne skåren sier lite om funksjonstapet som er relatert til spastisitet og er derfor ikke egnet til vurdering av behandlingseffekten. Det finnes en rekke andre skalaer, men de måler i liten grad funksjonstapet, og den kliniske nytteverdien er dermed begrenset (19-22). Individuell vurdering, gjerne ved hjelp av videoopptak før og etter behandling kan være nyttig for vurdering av effekt. Et viktig parameter vil alltid være om behandlingsmålene ble oppfylt.

Elektromyografi (EMG) kan brukes for å identifisere spastiske muskler, men kan ikke brukes for å vurdere grad av spastisitet eller bestemme behandlingsindikasjon $(8,15)$.

\section{Behandling}

Spastisitet kan påvirkes av en rekke faktorer. Pasienter med ryggmargsskade har helt eller delvis opphevet sensibilitet nedenfor skadenivået. Økende spastisitet kan være en reaksjon på sykdom eller skade nedenfor skadenivået. Derfor er det første steget å kartlegge og behandle alle tilstander som kan føre til forverring av spastisiteten (såkalte forsterkende faktorer) som urinveisinfeksjon, pneumoni, obstipasjon, menstruasjonssmerter, inngrodde negler, liggesår og liknende. Akutte, alvorlige infeksjoner og syringomyeli kan gi både økt spastisitet og plutselig fravær av spastisitet (fig 1).

Spastisitet motvirkes av systematisk motorisk stimulering. Egenaktivitet og behandling med tøyninger og bøyninger samt ståtrening kan derfor modulere spastisiteten. Dette bør startes umiddelbart hos alle pasienter med ryggmargsskade og spastisitet (23).

\section{Perorale medikamenter}

Spastisitet kan behandles medikamentelt, og perorale medikamenter er førstevalg både ved generell, regional og lokal spastisitet (fig 1). Perorale medikamenter har begrenset effekt, men er enkle å administrere. Baklofentabletter er det mest brukte medikamentet og det eneste rene muskulære spasmolytikum som er registrert i Norge. Baklofen er GABA-analog og inhiberer monosynaptiske og polysynaptiske spinale reflekser. Baklofen binder seg til $\mathrm{GABA}_{\mathrm{B}}$-reseptorer som er knyttet til kalium- og kalsiumkanaler både pre- og postsynaptisk (24). Effekten på spastisitet ble demonstrert $\mathrm{i}$ en kontrollert studie hos pasienter med ryggmargsskade, mens man $\mathrm{i}$ en annen studie ikke klarte å påvise denne effekten $(25,26)$. Den begrensede effekten av baklofen skyldes at kun en liten del av virkestoffet penetrerer blod-hjerne-barrieren (24). Bivirkninger forekommer hyppig, med sedasjon, kvalme, svimmelhet og respirasjonshemming som de vanligste (24). Man kan til en viss grad unngå bivirkninger ved langsom opptrapping. Epileptiske kramper, psykose og hypertermi er beskrevet ved plutselig seponering av medikamentet (27).

Et annet medikament som kan påvirke spastisitet er tizanidin. Dette medikamentet er ikke registrert i Norge og brukes derfor kun ved manglende effekt av baklofen. Tizanidin er et imidazolderivat og en sentral $\alpha$-adrenerg agonist som inhiberer frigjøringen av eksitatoriske aminosyrer i spinale internevroner (24). En studie demonstrerte uttalt muskelrelakserende effekt og suppresjon av polysynaptiske reflekser ved komplett ryggmargsskade (28). Tizanidin er vist å være effektivt i placebokontrollerte studier hos pasienter med ryggmargsskader (29, 30). Tizanidin og baklofen kan kombineres, men medikamentene har de samme potensielle bivirkningene, og disse kan bli mer fremtredende ved kombinasjon av medikamentene.

Benzodiazepiner kan ha effekt på spastisitet (24). Effekten er via påvirkning av $\mathrm{GABA}_{\mathrm{A}}$-reseptorsystemet. Sedasjon og kognitiv påvirkning er vanlige bivirkninger. Ved samtidig bruk av baklofen har benzodiazepiner en additiv effekt på spastisitet, men må administreres i små doser på grunn av like

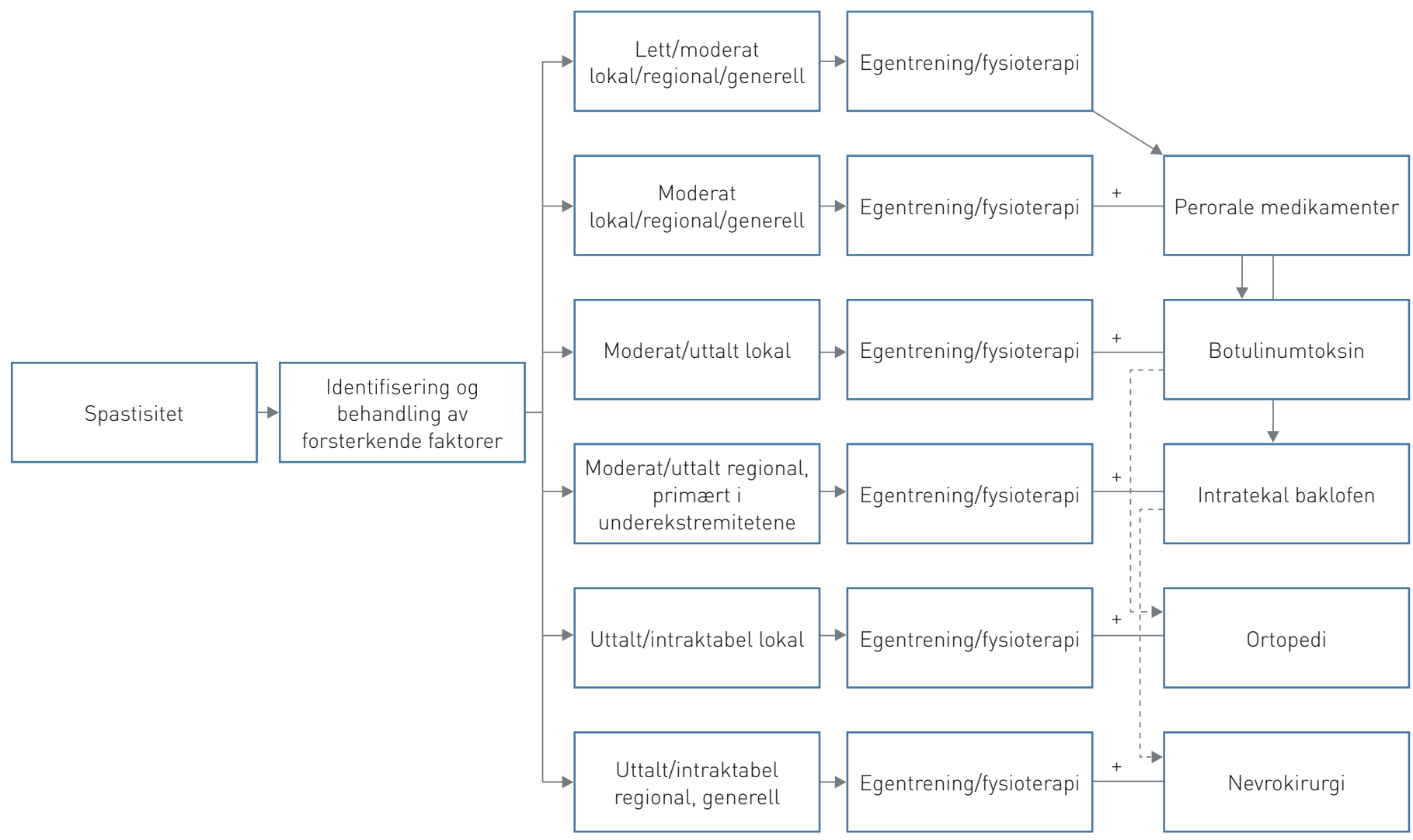

Figur 1 Håndtering av spastisitet etter grad og utbredelse 


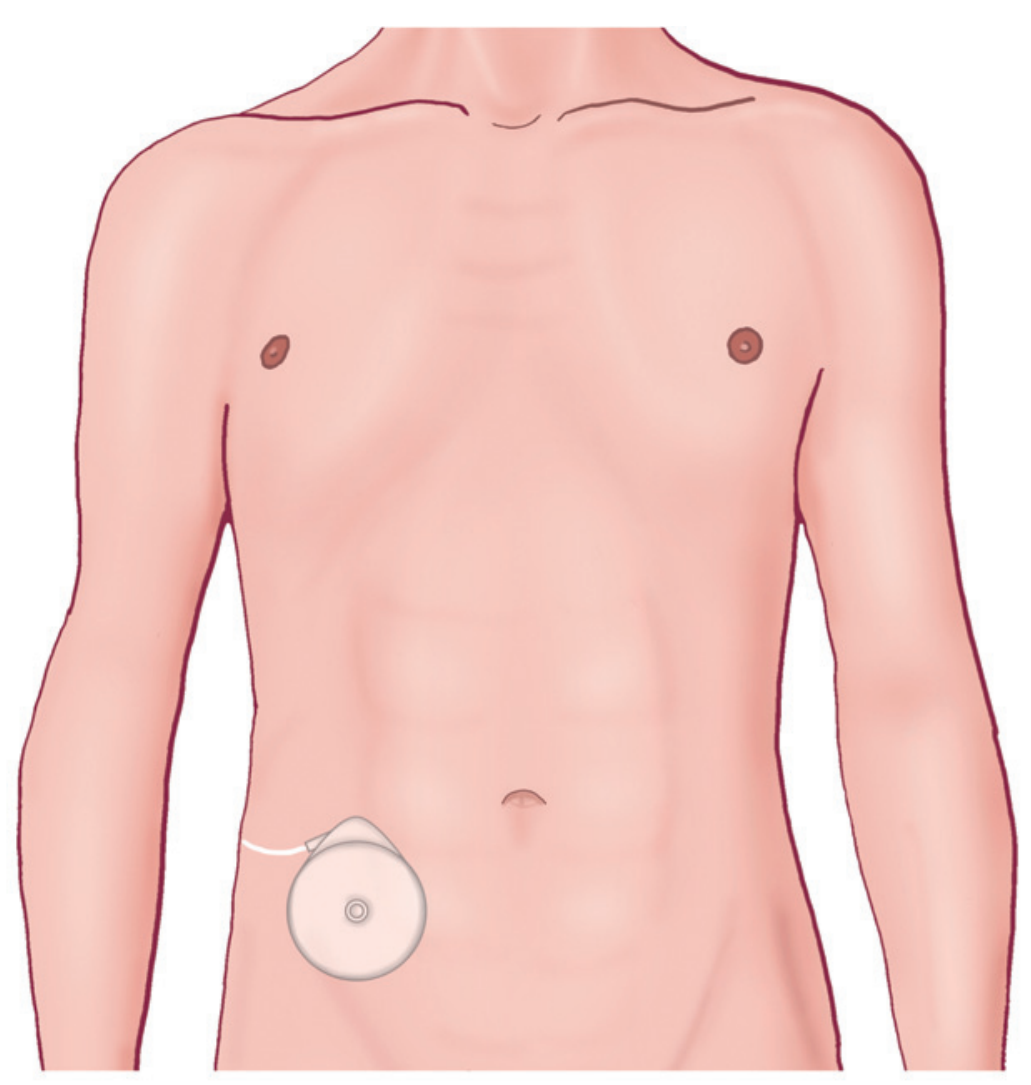

Figur 2 Implantert baklofenpumpe

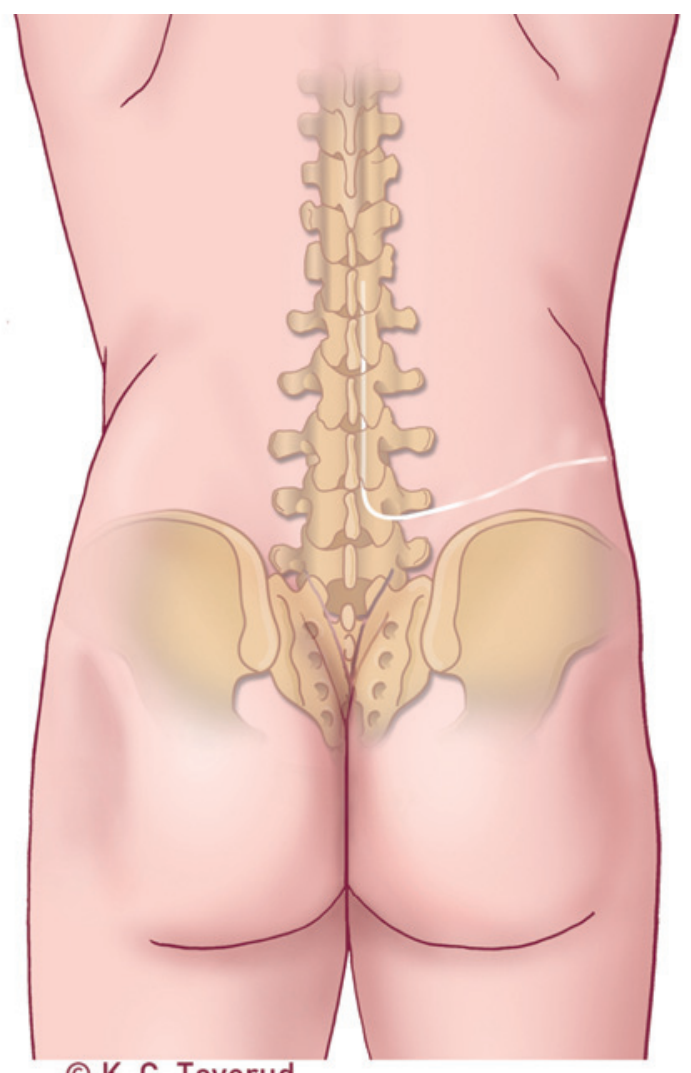

(c) K. C. Toverud bivirkninger som kan bli mer uttalte enn ved monoterapi (24). Benzodiazepiner blir ofte brukt i akutte tilfeller hvor man ønsker rask effekt og hensyn til bivirkninger er av underordnet betydning.

Klonidin og gabapentin kan ha spasmedempende virkning. Disse er lite brukt som spasmolytikum i klinisk praksis, og det er ikke gjennomført kliniske studier på ryggmargsskadede $(24,30)$.

Cannabispreparater har vært prøvd som medikamenter mot smerter og spastisitet, men resultater av studier har vært motstridende. Slike preparater er ikke anbefalt i behandlingen av spastisitet på grunn av et smalt terapeutisk område og fare for bivirkninger og avhengighet (31).

Lokale injeksjoner med botulinumtoksin Ved spastisitet kun i noen få muskler eller i en avgrenset muskelgruppe kan injeksjon med botulinumtoksin være et behandlingsalternativ. Botulinumtoksin er et produkt av Clostridium botulinum og blokkerer presynaptisk frigjøring av acetylkolin fra nerveterminaler slik at forbindelse mellom nerveterminal og muskelfiber blir avbrutt en periode. Botulinumtoksin svekker muskeltonus, og dermed kan parese bli mer fremtredende. Sju immunologisk distinkte toksiner er kjent (type A-G). Det vanligste er behandling med type A (Botox, Xeomin, Dysport), men type B (Neurobloc) kan også brukes. En forutsetning for vellykket behandling er at man på forhånd gjør en nøyaktig analyse og beskrivelse av funksjonen og vurderer hva man eventuelt kan oppnå med injeksjon i bestemte muskler.

Videre må man sikre at injeksjonene blir gitt i de korrekte musklene. Musklene kan identifiseres ved hjelp av enkanals-EMG, stimulator eller ultralyd (8). Effekten kommer gradvis i løpet av 1-3 dager etter injeksjonen, og maksimal effekt kan ses etter 5-14 dager. Virkningen avtar gradvis etter 12-16 uker (24). På grunn av faren for antistoffutvikling kan behandlingen gjentas tidligst etter tre måneder (32). Behandling med botulinumtoksin må være begrenset til få muskler, og man bør ikke injisere mer enn 50 enheter av Botox eller Xeomin (150 enheter Dysport) på samme sted (33). Den totale dosen per behandling bør ikke overstige 500 enheter Botox eller Xeomin (1500 enheter av Dysport). Beste effekt oppnås ved å kombinere botulinumtoksinbehandlingen med fysioterapi $(34,35)$. Botulinumtoksinbehandling gir stabil og forutsigbar effekt (36), hvilket er demonstrert hos pasienter med ryggmargsskade og en rekke andre tilstander $(36,37)$. Det finnes imidlertid ikke randomiserte studier på botulinumtoksinets effekt hos personer med ryggmargsskade. Randomiserte studier har etiske utfordringer, fordi det vil innebære mange injeksjoner med placebo i muskler.

\section{Intratekal infusjon av baklofen}

Ved regional spastisitet, spesielt i underekstremitetene, vil behandling med intratekal infusjon av baklofen via programmerbar pumpe være mer effektivt enn behandling med perorale medikamenter (8) (fig 2). Baklofen blir pumpet direkte til subaraknoidalrommet fra en programmerbar pumpe via et katetersystem. På denne måten reduseres systemiske effekter, og risikoen for bivirkninger er betydelig mindre (24). Før baklofenpumpen kan implanteres, må effekten av baklofen intratekalt testes ved at pasienten får en bolusdose via en vanlig spinalpunksjonsnål, alternativt kontinuerlig infusjon via ekstern pumpe. Etter implantasjonen kan dosen justeres via en programmerer, og pumpereservoaret må etterfylles med baklofen med jevne mellomrom. Behandling kan gis over lang tid, og effekten er vedvarende $(38,39)$. Det er ikke et absolutt øvre tak på doseringen. Daglige doser over $500 \mu \mathrm{g}$ kan gi bivirkninger, først og fremst i form av sedasjon.

Ved utbredt spastisitet i alle ekstremiteter er det vist at effekten av intratekal baklofen i overekstremitetene er anslagsvis kun $25 \%$ av effekten i beina (40). Ved spastisitet i både over- og underekstremitetene kan kombinasjonsbehandling med baklofenpumpe for spastisitet $\mathrm{i}$ underekstremitetene og botulinumtoksininjeksjoner for spastisitet i overekstremitetene være et godt alternativ. For å bevare gangfunksjonen, kan man forsøke å kombinere intratekal baklofen i lav dose og botulinumtoksin i enkelte muskler i underekstremitetene. På denne måten kan man mer målrettet dempe spastisiteten slik at pasienten får bedre kontroll med muskulatur og bevegelse og derved bevare gangfunksjon. 
Kirurgisk behandling av spastisitet

Kirurgisk behandling av spastisitet medfører irreversible forandringer og kan oftest unngås hvis andre tiltak er utført tidlig. Ortopediske inngrep kan brukes enten som eneste tiltak eller i kombinasjon med fysioterapi og botulinumtoksininjeksjoner ved lokal spastisitet (41). Hos utvalgte pasienter med intraktabel lokal spastisitet med deformasjoner i ledd, som for eksempel spissfot, kan man vurdere seneforlengelse, seneplastikk eller osteotomi (42). Ved uttalt regional spastisitet kan bakre, selektiv rhizotomi være et alternativ (43). Denne behandlingen er best egnet for pasienter med ikke-progredierende tilstander.

\section{Praktisk håndtering}

Spastisitet er ikke et statisk fenomen og bør følges opp både under og etter sykehusopphold. Alle pasienter med spastisitet bør oppfordres til egentrening. Ved utilstrekkelig effekt bør pasienten få fysioterapi med veiledning for øvelser som motvirker spastisiteten.

Perorale medikamenter kan forskrives av fastlegen. For behandling med botulinumtoksin bør pasienten henvises til nærmeste spesialist som kan tilby slik behandling. Vurdering, utprøving og implantering av baklofenpumpe utføres ved universitetsklinikkene. Observasjon og problembeskrivelse fra pasientens fastlege og fysioterapeut samt informasjon om pasientens andre sykdommer og tilstander er viktig for å kunne velge riktig behandlingsstrategi. Bruk av warfarin og tilstander som medfører økt blødningsfare kan være en relativ kontraindikasjon som bør vurderes før man anvender botulinumtoksin eller prøver ut intratekal baklofen. Påfyll og videre justering av pumpen utføres ved en rekke sykehus i Norge. Pasienten bør få tilbud ved nærmeste sykehus for å unngå lang reisevei. Før vurdering av ortopediske eller nevrokirurgiske inngrep bør alle andre tiltak være prøvd ut.

\section{Tiina Rekand (f. 1960)}

er dr.med. og spesialist i nevrologi. Hun jobber som overlege for Spinalenheten, Nevrologisk avdeling. Haukeland universitetssykehus Og er medlem av styret for det norske ryggmargsskaderegisteret. Hun har vært knyttet til Spastisitetsklinikken ved Nevrologisk avdeling. Haukeland universitetssykehus fra 2003 Oppgitte interessekonflikter: Har deltatt på kongressreiser sponset av Desitin og Allergan.

\section{Ellen Merete Hagen (f. 1962)}

er spesialist i nevrologi og i samfunnsmedisin. Hun er assistentlege ved Seksjon for klinisk nevrofysiologi, Nevrologisk avdeling, Haukeland universitetssjukehus og har doktorgrad i epidemiologi ved traumatiske ryggmargsskader fra Universitetet i Bergen. Hun er postdoktor ved Universitetet i Bergen.

Ingen oppgitte interessekonflikter.

\section{Marit Grønning (f. 1955)}

er dr.med. og spesialist i nevrologi. Hun er overlege ved Nevrologisk avdeling, Haukeland universitetssykehus og professor ved Institutt for klinisk medisin, Universitetet i Bergen. Ingen oppgitte interessekonflikter.

\section{Litteratur}

1. Johnson RL, Gerhart KA, McCray J et al. Secondary conditions following spinal cord injury in a population-based sample. Spinal Cord 1998; 36 $45-50$

2. Noreau L, Proulx $P$, Gagnon L et al. Secondary impairments after spinal cord injury: a populationbased study. Am J Phys Med Rehabil 2000; 79 $526-35$.

3. Levi R, Hultling C, Nash MS et al. The Stockholm spinal cord injury study: 1. Medical problems in a regional SCI population. Paraplegia 1995; 33: $308-15$.

4. Sköld C, Levi R, Seiger A. Spasticity after traumatic spinal cord injury: nature, severity, and location. Arch Phys Med Rehabil 1999; 80: 1548-57.

5. Lance JW. The control of muscle tone, reflexes, and movement: Robert Wartenberg Lecture. Neurology 1980; 30: 1303-13.

6. Stevenson VL. Rehabilitation in practice: Spasticity management. Clin Rehabil 2010; 24: 293-304.

7. Ward AB. Spasticity treatment with botulinum toxins. J Neural Transm 2008; 115: 607-16.

8. Elbasiouny SM, Moroz D, Bakr MM et al. Management of spasticity after spinal cord injury: current techniques and future directions. Neurorehabil Neural Repair 2010; 24: 23-33

9. Saval A, Chiodo AE. Intrathecal baclofen for spasticity management: a comparative analysis of spasticity of spinal vs cortical origin. J Spinal Cord Med 2010; 33: 16-21

10. Gracies J-M. Pathophysiology of spastic paresis. I: Paresis and soft tissue changes. Muscle Nerve 2005: 31: 535-51

11. Gracies J-M. Pathophysiology of spastic paresis II: Emergence of muscle overactivity. Muscle Nerve 2005; 31: 552-71

12. Adams MM, Hicks AL. Spasticity after spinal cord injury. Spinal Cord 2005; 43: 577-86.

13. Green D, Hartwig D, Chen D et al. Spinal Cord Injury Risk Assessment for Thromboembolism (SPIRATE Study). Am J Phys Med Rehabil 2003; 82: $950-6$

14. Murphy NA. Deep venous thrombosis as a result of hypotonia secondary to intrathecal baclofen therapy: a case report. Arch Phys Med Rehabil 2002; 83: 1311-2.

15. Yelnik AP, Simon O, Parratte B et al. How to clinically assess and treat muscle overactivity in spastic paresis. J Rehabil Med 2010; 42: 801-7.

16. Lechner HE, Frotzler A, Eser P. Relationship between self- and clinically rated spasticity in spinal cord injury. Arch Phys Med Rehabil 2006: 87: $15-9$

17. Ashworth B. Preliminary trial of carisopodol in multiple sclerosis. Practitioner 1964: 192: 540-2.

18. Fleuren JF, Voerman GE, Erren-Wolters CV et al. Stop using the Ashworth Scale for the assessment of spasticity. J Neurol Neurosurg Psychiatry 2010 81: $46-52$.

19. Tardieu G, Shentoub S, Delarue R. A la recherché d'une technique de mesure de la spasticité. Rev Neurol 1954; 91: 143-4

20. Mehrholz J, Wagner K, Meissner D et al. Reliability of the Modified Tardieu Scale and the Modified Ashworth Scale in adult patients with severe brain injury: a comparison study. Clin Rehabil 2005; 19: $751-9$

21. Penn RD, Savoy SM, Corcos D et al. Intrathecal baclofen for severe spinal spasticity. N Engl J Med 1989: 320: 1517-21.

22. Priebe MM, Sherwood AM, Thornby JI et al. Clinical assessment of spasticity in spinal cord injury: a multidimensional problem. Arch Phys Med Rehabil 1996: 77: 713-6.

23. Gracies JM. Pathophysiology of impairment in patients with spasticity and use of stretch as a treatment of spastic hypertonia. Phys Med Rehabil Clin N Am 2001; 12: 747-68.
24. Kita M, Goodkin DE. Drugs used to treat spasticity. Drugs 2000; 59: 487-95

25. Hinderer SR, Lehmann JF, Price R et al. Spasticity in spinal cord injured persons: quantitative effects of baclofen and placebo treatments. Am J Phys Med Rehabil 1990; 69: 311-7

26. Burke D, Gillies JD, Lance JW. An objective assessment of a gamma aminobutyric acid derivative in the control of spasticity. Proc Aust Assoc Neurol 1971; 8: 131-4.

27. Dario A, Tomei G. A benefit-risk assessment of baclofen in severe spinal spasticity. Drug Saf 2004 27: 799-818

28. Milanov I, Georgiev D. Mechanisms of tizanidine action on spasticity. Acta Neurol Scand 1994; 89: $274-9$.

29. Nance PW, Bugaresti J, Shellenberger K et al. Efficacy and safety of tizanidine in the treatment of spasticity in patients with spinal cord injury. Neurology 1994; 44 (suppl 9): S44-51.

30. Taricco M, Pagliacci MC, Telaro E et al. Pharmacological interventions for spasticity following spinal cord injury: results of a Cochrane systematic review. Eura Medicophys 2006; 42: 5-15.

31. Karst M, Wippermann S, Ahrens J. Role of cannabinoids in the treatment of pain and (painful) spasticity. Drugs 2010; 70: 2409-38.

32. Müller K, Mix E, Adib Saberi F et al. Prevalence of neutralising antibodies in patients treated with botulinum toxin type A for spasticity. J Neural Transm 2009; 116: 579-85.

33. Wissel J, Ward AB, Erztgaard P et al. European consensus table on the use of botulinum toxin type A in adult spasticity. J Rehabil Med 2009; 41: 13-25.

34. Giovannelli M, Borriello G, Castri P et al. Early physiotherapy after injection of botulinum toxin increases the beneficial effects on spasticity in patients with multiple sclerosis. Clin Rehabil 2007 21: $331-7$

35. Smedal T, Gjelsvik B, Lygren $\mathrm{H}$ et al. Botulinum toksin A- effekt på spastisitet. Tidsskr Nor Lægeforen 2001; 121: 3277-80

36. Naumann M, Albanese A, Heinen F et al. Safety and efficacy of botulinum toxin type A following long-term use. Eur J Neurol 2006; 13 (suppl 4): $35-40$

37. Marciniak C, Rader L, Gagnon C. The use of botulinum toxin for spasticity after spinal cord injury. Am J Phys Med Rehabil 2008; 87: 312-7, quiz 318-20, 329

38. Coffey JR, Cahill D, Steers W et al. Intrathecal baclofen for intractable spasticity of spinal origin: results of a long-term multicenter study. J Neurosurg 1993; 78: 226-32.

39. Koulousakis A, Kuchta J. Intrathecal antispastic drug application with implantable pumps: results of a 10 years follow-up study. Acta Neurochir Suppl (Wien) 2007; 97: 181-4.

40. Guillaume D, Van Havenbergh A, Vloeberghs $M$ et al. A clinical study of intrathecal baclofen using a programmable pump for intractable spasticity. Arch Phys Med Rehabil 2005; 86: 2165-71.

41. Lynn AK, Turner M, Chambers HG. Surgical management of spasticity in persons with cerebral palsy. PM R 2009; 1: 834-8.

42. Smyth MD, Peacock WJ. The surgical treatmen of spasticity. Muscle Nerve 2000; 23: 153-63.

43. Grønning M, Svendsen F, Skeidsvoll $H$ et al. Spastisitet behandlet med selektiv bakre rhizotomi. Tidsskr Nor Lægeforen 2002; 122: 1190-1.

Mottatt 18.8. 2010, første revisjon innsendt 18.4 2011, godkjent 3.11. 2011. Medisinsk redaktør Siri Lunde. 